Anna Maria Czernow

Uniwersytet Warszawski

\title{
Heroska pokoju dziecinnego. \\ Pippi Pończoszanka jako głos rewolucji ideologicznej w literaturze dziecięcej
}

\author{
The Hero of the Nursery. Pippi Longstocking as a Voice \\ of Ideological Revolution in Children's Literature
}

Astrid Lindgren's Pippi Longstocking, designed as a radically subversive character, is the antichild. Given power and independence, she discloses culture-defined relations between children and adults and promotes a sentiment-free commentary that highlights the inherent status of inequality in these relations and the resulting oppression. Placed by the author at the top of the hierarchy, she subverts this oppression: all of a sudden, now it is adults that are exposed to the activities of the unpredictable, rollicking, carnivalesque girl. The result of this narrative device is laced with the intense, insolvable conflict of two antagonistic tribes: children and adults. In this war, Pippi plays a leading role. She is the heroine of the marginalized space of the nursery.

Key words: Fool figure, carnival, heroine, anti-child system, power

Słowa klucze: błazen, karnawał, heros, antydziecko, władza

W kwietniu 1944 roku Astrid Lindgren wysłała pierwszą wersję manuskryptu Pippi Långstrump do wydawnictwa Bonniers. Książce towarzyszył list, w którym można przeczytać między innymi:

Pippi Pończoszanka jest [...] małym Übermenschem w dziecięcej postaci, wprowadzonym w całkowicie zwyczajne otoczenie. Dzięki swoim nadnaturalnym mocom i różnym innym okolicznościom jest ona całkowicie niezależna od jakichkolwiek dorosłych i żyje dokładnie tak, jak jej się podoba, a w starciach z dużymi ludźmi zawsze ma ostatnie słowo (Lundqvist 2007: 111).

1 Cytaty ze źródeł obcojęzycznych, jeśli nie podano inaczej, przytaczam we własnym tłumaczeniu. 
Manuskrypt został odrzucony. Publikacji podjęła się rok później oficyna Rabén \& Sjögren pod warunkiem dokonania zmian w tekście. Zajęła się tym sama autorka we współpracy z Elsą Olenius, ważną postacią w ówczesnym środowisku kultury dla niedorosłych (Andersen 2014: 203). W 2007 roku pierwotny manuskrypt został opublikowany w jubileuszowej serii dzieł wszystkich Lingren pod zaproponowanym przez Ullę Lundqvist tytułem Ur-Pippi.

Postać Pippi Pończoszanki, dziecka obdarzonego nadnaturalną siłą, można interpretować w kontekście mitów heroicznych. Jej witalność i aktywność wyrażają się w ciągłej gotowości do podejmowania wyzwań, takich jak: walka $\mathrm{z}$ bykiem, tygrysem czy rekinem, wyniesienie z pożaru dzieci, poskromienie złodziei czy znęcającego się nad koniem gospodarza, a wreszcie udzielenie nauczki lokalnemu chuliganowi. Wszystkie te czyny skutkują następującą konkluzją lokalnej społeczności: „- Nie potrzebujemy w mieście żadnej policji [...], póki mamy Pippi Pończoszankę. [...] ona umie sobie poradzić i z tygrysami, i z chuliganami” (Lindgren 2011: 168). Działalność Pippi zostaje zatem explicite zidentyfikowana jako stanie na straży porządku, co w świecie mitycznych opowieści było zadaniem herosów.

Jednak bohaterka trylogii Lindgren jest również dzieckiem - postacią z perspektywy obowiązującej normy marginalną, pozbawioną głosu i prawa do inicjatywy. W kontekście mitów heroicznych jest zatem swoistym antyherosem niczym błazeński król głupców (Sznajderman 2000: 112). Antyheroiczna strona działalności Pippi wyraża się w prometejskim buncie wobec reguł obowiązującej normy i stojącej za nimi bezwzględnej opresji świata dorosłych. Kwintesencją jej aktywności na kartach trylogii Lindgren jest zatem ustawiczne tych reguł lekceważenie, ośmieszanie, a wreszcie łamanie, innymi słowy - celebracja chaosu na gruzach skompromitowanej normatywnej struktury. Owa buntownicza działalność da się interpretować zarówno w aspekcie estetycznym (Kåreland 1999: 274-312), jak i ideologicznym. Ten ostatni związany jest bezpośrednio z pedagogicznym ideałem, który w każdym okresie rozwoju literatury dla niedorosłych manifestował się w jej dydaktycznym nurcie. W czasie gdy Pippi miała ujrzeć światło dzienne, ideał ten wciąż powielał dziewiętnastowieczne schematy, zgodnie z którymi „dzieci należy ujarzmiać i cywilizować” (Bergstrand 1999: 59), a dorosły to ten, który ma monopol na prawdę i rację (Cieślikowski 1975: 96). W tym kontekście ideologiczny bunt Pippi wybrzmiewa szczególnie wyraziście. Potworami, przeciw którym skierowana jest jej zasadnicza krucjata, są bowiem dorośli. Strącając ich z piedestału, Lindgrenowska bohaterka obnaża i kompromituje mroczne oblicze kreowanego przez nich skostniałego porządku, stając się heroską przestrzeni marginalnej - pokoju dziecinnego.

Efekt „na opak” w największym stopniu dotyczy tu samej istoty dziecięcości, jako że konstrukcja postaci Pippi w całości zasadza się na napięciu między oficjalnym wzorcem dziecka idealnego, proklamowanym przez dydaktyczną literaturę 
dla niedorosłych, a karnawałowym $\mathrm{w}$ charakterze modelem ludycznym, pochodzącym wprost $\mathrm{z}$ dziecięcego folkloru. Rola dziecka w wykonaniu Pippi podobna jest zatem do odbicia w błazeńskim zwierciadle - zniekształca proporcje i rozbija zasady, wykrzywia i ośmiesza. Obdarzona całkowitą niezależnością bohaterka wywraca na opak - dosłownie i w przenośni - wszystkie składowe dziecięcości wpisanej w światopogląd będący źródłem ówcześnie akceptowanej normy kulturowej. Skutecznie i bezlitośnie obnaża absurd i niesprawiedliwość reguł panujących w relacjach dzieci - dorośli, a w starciu z tymi ostatnimi „zawsze ma ostatnie słowo”. To właśnie czyni ją dziecięcą heroską czy też - jak zostało to określone w przytoczonym wyżej liście do wydawcy - „małym Übermenschem”. Podkreślić należy bezkompromisowość i odwagę Lindgren, która w 1944 roku użyła w odniesieniu do swej bohaterki skompromitowanego Nietzscheańskiego ${ }^{2}$ terminu „nadczłowiek”, czym świadomie narażała się na skandal i efekt moralnej paniki. Jednak tym aktem autointerpretacji zainspirowała szereg krytyków i badaczy: „nadczłowiekiem”, „naddzieckiem” lub „superdzieckiem”3 nazywali Pippi między innymi Ingermar Vizelius, Vibeke Stybe i Bettina Hürlimann (Lundqvist 1979: 141), a słynny badacz niemiecki Klaus Doderer stwierdził wręcz, że Pippi jest świadomą odpowiedzią na barbarzyństwa Hitlera (Edström 1992: 101).

Owo „nad” wpisane w konstrukcję postaci Pippi jako superdziecka połączone jest ściśle z wynikającym z jej natury „anty”. Podejmując antyheroiczną działalność względem otaczającej ją rzeczywistości, sama Pippi Pończoszanka funkcjonuje jako antydziecko. Karnawałowy, odwrotny charakter dziecięcości Pippi kształtuje się poprzez kontrast, i to zarówno na poziomie wewnątrztekstowym, jak i intertekstualnym. W warstwie fabuły i konstrukcji świata przedstawionego tytułowa bohaterka ustawia się w stałej opozycji do pozostałych opisanych w tekście postaci dziecięcych. W perspektywie intertekstualnej stanowi komentarz do typowych głównych heroin rodem z tradycyjnych powieści dla dziewcząt.

Najważniejszymi oprócz Pippi dziećmi w trylogii są bez wątpienia jej towarzysze zabaw - Tommy i Annika, podsumowani w tekście tomu pierwszego następującym opisem:

Było to dwoje bardzo grzecznych, dobrze wychowanych i posłusznych dzieci. Tommy nigdy nie ogryzał paznokci i zawsze robił to, o co go mamusia poprosiła. Annika zaś nie naprzykrzała się, gdy nie mogła postawić na swoim i zawsze wyglądała schludnie w gładko wyprasowanych, kretonowych sukienkach, których starała się nie zabrudzić (Lindgren 2011: 7-8).

\footnotetext{
2 Zaznaczyć należy, że cytat z Tako rzecze Zaratustra Nietzschego posłużył Ellen Key jako motto do Stulecia dziecka (Key 1900: IV) - traktatu pedagogicznego bardzo istotnego dla Lindgren.

3 Tworząc sylwetkę Pippi, Lindgren w znacznym stopniu inspirowała się kulturą popularną, filmami oraz komiksami, m.in. tym o Supermanie (Andersen 2014: 184).
} 
Według Lundqvist literatura dla młodych odbiorców jest skarbnicą wiedzy dla tych badaczy, których celem jest odtworzenie ideału wychowawczego danej epoki (Lundqvist 1979: 15). Bohaterowie utworów spod znaku tego ideału zaopatrywani byli zazwyczaj w starannie dobrany zespół cech, by dla odbiorcy być przykładem pozytywnym bądź negatywnym, przy czym cel wychowawczy wymagał, aby przekaz był klarowny i nieskomplikowany. Charakterystyczne są zwłaszcza powiastki dydaktyczne, które poprzez bezlitosne piętnowanie dziecięcych grzechów $\mathrm{z}$ jednej strony, a chwalenie zestawu pożądanych zachowań z drugiej przyczyniły się do wytworzenia wzorca składającego się z takich atrybutów, jak: posłuszeństwo, potulność, schludność, prawdomówność, powściągliwość i pracowitość. Ta uniwersalna lista była jeszcze aktualna w pierwszej połowie XX wieku, czego dowodem jest strategia konstrukcyjna zastosowana w kreacji postaci Tommy'ego i Anniki - grzecznych bohaterów trylogii o Pippi. Już z przytoczonego fragmentu, wprowadzającego rodzeństwo do świadomości odbiorcy, wyczytać można niektóre z wymienionych cech - posłuszeństwo, potulność oraz schludność. Pozostałe przymioty ujawniają się wraz z rozwojem fabuły: dzieci milczą niepytane, pilnie przykładają się do nauki i wprost brzydzą się kłamstwem.

Annika w kraciastej sukience i Tommy w marynarskim ubranku, czyściutcy i gładko uczesani, to stereotypowe figurynki ze starych fotografii, dzieci-roboty według określenia Vivi Edström (1992: 92) lub też - jak proponuje Lundqvist dzieci-marionetki (Lundqvist 1979: 133). Znamienne, że w pierwotnej wersji manuskryptu marionetkowość rodzeństwa zaznacza sama Pippi, w następujący sposób kwitując ich obecność na swojej drodze: „Witam was, drogie dzieciaczki w kratkę! Nazywam się Pippi Pończoszanka. Wasze imiona niewątpliwie poznam z czasem. Pozwólcie sobie przedstawić pana Nilssona!" (Lindgren 2007: 15). Charakterystyczny jest tu brak zainteresowania dla imion rodzeństwa, które zostaje zredukowane do roli przypadkowych, pozbawionych indywidualności reprezentantów dziecięcej populacji miasteczka. Ustęp ten padł ofiarą przeróbek autorki w ramach działań zmierzających do złagodzenia radykalnego wizerunku tytułowej bohaterki ${ }^{4}$.

W tak ukierunkowanej kreacji przyjaciół Pippi Edström dostrzega autorską chęć zbudowania kontrastu dla szalonych zachowań tytułowej bohaterki (Edström 1992: 92), Lundqvist zaś interpretuje ją jako szersze zamierzenie konstrukcyjne. Według badaczki stereotypowość postaci Tommy’ego i Anniki, reprezentujących "tłum chodzących wzorów cnót, zaludniający literaturę dla dzieci tamtego czasu” (Lundqvist 1979: 133), sprawia, że nie da się widzieć w nich realistycznych bohaterów dziecięcych. Wraz z pozostałymi, równie stereotypowymi mieszkańcami miasteczka stanowią „raczej koncepcje niż osobowości” (Lundqvist 1979: 133), a to

4 W opublikowanej wersji rozmowę zaczyna Tommy, pytając Pippi o przyczynę poruszania się tyłem. 
czyni ich postaciami w równym stopniu fantastycznymi co sama Pippi. „Dzieci-roboty” u Lindgren pozbawione są głębi psychologicznej, ponieważ reprezentują wpisaną w rzeczywistość przedstawioną normę kulturową, z którą konfrontuje się roześmiany karnawałowy błazen - Pippi.

Zarówno Edström, jak i Lundqvist podkreślają istotność faktu, że Pippi jest postacią dziewczęcą, a w orbicie jej destrukcyjnej działalności znajduje się rozbijanie i wyszydzanie normatywnego wzorca nierównych statusów kobiety i mężczyzny (Lundqvist 1979: 133; Edström 1992: 56). Cechami kulturowo pożądanymi u małych dziewczynek były potulność, nieśmiałość, strachliwość oraz bierność, znakomicie korespondujące $\mathrm{z}$ przeznaczoną im w patriarchalnym porządku społecznym niepubliczną, domową sferą życia (Rowbotham 1989: 11). Wszelka aktywność czy to fizyczna, czy intelektualna - stanowiła godny potępienia akt transgresji skutkujący bytowaniem w liminalnej, niezdefiniowanej sferze pomiędzy dziewczęcością a chłopięcością, co łączyło się z przyjęciem niebezpiecznej roli chłopczycy (Abate 2008). W trylogii Lindgren odwaga, niezależność i beztroska Pippi zostały skontrastowane z biernością, potulnością i strachliwością Anniki, która - jeśli posłużyć się określeniem Lundqvist - bardziej niż aktywny Tommy przypomina marionetkę. Destrukcyjne wobec normatywnych reguł zachowanie Pippi ośmiesza stereotypową dziewczynkowatość Anniki. Planując wraz z Tommym wspólną awanturniczą przyszłość w roli krwawych piratów, w następujący sposób reaguje na wyrażoną przez Annikę niechęć dla takich planów: „Ach, możesz nam przecież towarzyszyć [...]. I odkurzać fortepian!” (Lindgren 2011: 179). Ciągłe zderzanie tych dwóch modeli dziewczęcości pozwala osiągnąć groteskowy efekt karykatury, służący uwypukleniu karnawałowego buntu tytułowej bohaterki.

Na poziomie intertekstualnym w kreacji Pippi Pończoszanki widoczne są nawiązania do wydanej w 1908 roku powieści Ania z Zielonego Wzgórza autorstwa Lucy Maud Montgomery. Utwór ten wywarł ogromne wrażenie na Lindgren i niewątpliwie był jedną z najważniejszych lektur jej dzieciństwa, o czym świadczyć może następujące wspomnienie:

I oczywiście... Ania z Zielonego Wzgórza, och ty moja niezapomniana, zawsze już będziesz jechać bryczką obok Mateusza Cuthberta pod kwitnącymi gałęziami wiśni w Avonlea! Jakże ja żyłam tą dziewczynką! Całe lato bawiłam się z moimi siostrami w Anię z Zielonego Wzgórza na wielkim stosie trocin przy tartaku, ja byłam Dianą Barry, a gnojówka za oborą była Jeziorem Lśniących Wód (Lindgren 1964: 129).

Na pokrewieństwo Pippi z Anią zwracało uwagę wielu badaczy (Metcalf 1995: 64; Lundqvist 1979: 129; Edström 1992: 89), podkreślając między innymi cechy wyglądu (rude włosy, piegi, nadmierna chudość) oraz status życiowy (sieroctwo) obu bohaterek. Eva-Maria Metcalf doszukuje się odniesienia intertekstualnego w samej nazwie Willi Śmiesznotki, która w szwedzkim oryginale brzmi „Villa 
Villekulla”, co według badaczki stanowi „żartobliwe nawiązanie do Grönkulla, szwedzkojęzycznej nazwy domu Ani z Zielonego Wzgórza. Grönkulla [...] staje się w Pippi Pończoszance Villekullą. 'Villervalla' znaczy po szwedzku nieporządek lub chaos, a właśnie chaos Pippi wprowadza do powieści dla dziewcząt” (Metcalf 1995: 64-65). Edström interpretuje odniesienia do Ani z Zielonego Wzgórza rozsiane $\mathrm{w}$ tekście trylogii $\mathrm{w}$ kategoriach ironii i parodii, podkreślając, że Pippi można czytać jako karykaturę bohaterki tradycyjnej powieści dla dziewcząt, „gdzie najgorsze, co mogło takową spotkać, sprowadzało się do piegów i rudych włosów" (Edström 1992: 88). W odniesieniu do tej diagnozy można stwierdzić, że biorąc Anię Shirley za bezpośrednie źródło inspiracji, Lindgren przeprowadza rodzaj konstruktywnej krytyki ideologicznej wymowy utworów Montgomery. To, co dla Ani było źródłem rozpaczy: rude włosy, obfitość piegów, wieczne przeszkody na drodze do godnego (normatywnego) zachowania, w przypadku Pippi stanowi powód kolejnych erupcji samozadowolenia. W trylogii odnaleźć można bezpośrednie nawiązania do poszczególnych epizodów zawartych w cyklu Montgomery, takich jak niefortunna przygoda $\mathrm{z}$ farbą do włosów, która w efekcie nadała rudym włosom Ani zielony odcień, czy opis omyłkowego zastosowania czerwonego barwnika do tkanin zamiast maści na pozbycie się piegów z nosa. Oba te epizody, jak i wiele innych, pełnią w utworach Montgomery charakterystyczną dla klasycznej powieści dziewczęcej funkcję „ujarzmiania chłopczycy" (Abate 2008). Nadmierna ekspresja Ani, jej nieokiełznana wyobraźnia, bujny temperament oraz niecierpliwość intelektualna wymagają poskromienia, sama zaś bohaterka musi wpisać się w normatywny wzorzec potulnej i cichej dziewczęcości. W przypadku Pippi nie ma mowy o ujarzmianiu czy poskramianiu. Uosabiając, jak twierdzi Metcalf, triumfującą „radosną anarchię” (Metcalf 1995: 63), bohaterka Lindgren trwa w niezmiennej postawie samozadowolenia. Określając swoją powierzchowność jako „prześliczną” lub „czarującą”5, prezentuje zachwyt nad marchewkowym kolorem swoich włosów i nie stroni od intertekstualnych kpin z nieszczęść kanadyjskiego pierwowzoru: „- Myślisz, że czarny kolor będzie pasował do twoich rudych włosów? - powątpiewała Annika. - Zobaczymy - odparła Pippi. - To przecież drobiazg przefarbować włosy na zielono" (Lindgren 2011: 198).

Pewność siebie i samozachwyt Pippi stoją w jaskrawej sprzeczności nie tylko z postawą jej literackiej poprzedniczki, ale z ogólniejszym obrazem dziecka ukształtowanym w ówczesnej literaturze dla dzieci oraz w ówczesnych tradycjach wychowawczych. Według Lundqvist: „Fakt, że Pippi jest zadowolona z siebie, że siebie akceptuje, jest [...] czymś zupełnie nowym w książkach dla dzieci - a prze-

W oryginale förtjusande, słowo według Edström nawiązujące do Ani z Zielonego Wzgórza, która w szwedzkim tłumaczeniu tego właśnie określenia nadużywa (Edström 1992: 89). 
cież powieść została napisana w czasach, kiedy "prawo Jante» ${ }^{6}$ nadal było wiodącą regułą w wychowaniu dzieci" (Lundqvist 1979: 134). Pippi sprzeciwia się tej regule na różne sposoby, a zamiast odgrywać społecznie akceptowaną rolę skromnego, cichego i potulnego dziecka, „lubi być widziana i słyszana”, jak twierdzi Edström (1992: 89), nawiązując do popularnego powiedzenia, według którego dzieci powinno się widzieć, ale nie powinno się ich słyszeć.

Jako antydziecko Pippi Pończoszanka łamie ustalone reguły na wszystkich możliwych poziomach, ucieleśniając model niegrzeczności doskonałej. Oprócz celebracji brudnego ciała i nadmierniego eksponowania fizjologii, oprócz gargantuicznego objadania się przy każdej możliwej okazji, ryzykownych zachowań, takich jak skok z wysokiego kamienia powodowany przeświadczeniem o umiejętności latania, Pippi popełnia jedno z kardynalnych wykroczeń przeciw dziecięcemu dekalogowi - kłamie.

Według Edström mitomaństwo Pippi należy interpretować w kategoriach ideologicznych jako sprzeciw wobec „wrogiego dzieciom wymogu prawdy” (Edström 1992: 110). Zdaniem Ellen Buttenschøn kłamstwa bohaterki Lindgren to metoda przywrócenia równowagi władzy pomiędzy dziećmi a dorosłymi (Edström 1992: 110). Natomiast w kontekście błazeńskiej natury działalności Pippi można stwierdzić, że jej kłamstwa służą obnażeniu i ośmieszeniu obłudy dorosłych, a zwłaszcza nieprawdziwości oficjalnego obrazu świata konstruowanego na potrzeby manipulowania dziećmi. Znakomitym tego przykładem jest fantazyjna opowieść, którą Pippi raczy przygodną dziewczynkę mijającą furtkę Willi Śmiesznotki w poszukiwaniu tatusia:

Widziałam kiedyś w Szanghaju Chińczyka. Uszy jego były tak wielkie, że mógł ich używać jako peleryny. [...] Miał tyle dzieci, że nie potrafił ich zliczyć, a najmniejsze z nich miało na imię Petter. [...] Taki był niejadek, że matka jego strasznie cierpiała. [...] Lecz Petter zaciskał tylko usta i potrząsał przecząco głową. W końcu Hai Shang rozzłościł się i powiedział, że nie będzie się dla smyka gotować żadnego nowego jedzenia, zanim nie zje jednego gniazda jaskółczego za zdrowie tatusia. [...] To samo gniazdo jaskółcze wynoszono z kuchni i wnoszono z powrotem - od maja do października. [...] Petter zaciskał uporczywie usta od maja do października. [...] Umarł. Z głupiego oślego uporu. [...] Pogrzeb odbył się dziewiętnastego. A dwudziestego wleciała przez okno jaskółka i zniosła jajka w gnieździe, które stało na stole. Przydało się w każdym razie. No i w ten sposób nie poniesiono właściwie żadnej straty (Lindgren 2011: 44-46).

Opowieść o małym Petterze odwołuje się do jednego z podstawowych grzechów dzieciństwa opisywanych w tradycyjnej literaturze dla dzieci - odmowy jedzenia. Jej struktura przypomina XIX-wieczną powiastkę dydaktyczną: nieposłuszeństwo

\footnotetext{
6 Terminu „prawo Jante” po raz pierwszy użył duński pisarz norweskiego pochodzenia Aksel Sandemose w wydanej w 1933 r. powieści Uciekinier przecina swój ślad (Sandemose 2019). W potocznym rozumieniu termin ten oznacza zakaz wyróżniania się i zwracania na siebie uwagi.
} 
skutkuje karą, w tym wypadku karą śmierci, co nie odbiega zbytnio od standardów wyznaczonych w ramach tego gatunku. Opowieść Pippi najprawdopodobniej stanowi nawiązanie intertekstualne do Historii bardzo smutnej o chtopcu, który nie chciat jeść $z u p y^{7}$ wchodzącej w skład klasycznego zbiorku Heinricha Hoffmanna Złota różdżka. Bohater powiastki podobnie jak Petter odmawiał przyjmowania pożywienia, co skończyło się jego zgonem. Jednak podczas gdy agonia Pettera rozciąga się na wiele miesięcy (od maja do października), co każe słuchaczom powątpiewać w jej prawdopodobieństwo, śmierć Michasia następuje w terminie absurdalnie krótkim ${ }^{8}$ od momentu pierwszego aktu nieposłuszeństwa:

Nazajutrz Michaś tak schudł niebożę,

Że go nikt w domu poznać nie może. [...]

Na trzeci dzionek, bieda nie żarty.

I schudł i osłabł Michaś uparty. [...]

W czwartym dniu Michaś wychudł jak nitka,

W piątym coś w piersiach i w gardle dusi:

Kto nie je zupy, ten umrzeć musi.

Tak też z Michasiem! Był zdrów i tłusty,

Pięć dni grymasił, umarł na szósty.

(Hoffmann 1933: 16)

Szczególną uwagę w historii o Petterze zwraca ostrze krytyki wymierzone $\mathrm{w}$ bezlitosną logikę wpisaną $\mathrm{w}$ utwór Hoffmanna, zgodnie z którą dziecięcy bohater odarty jest z wszelkich cech indywidualnych, a w opowieści pełni wyłącznie funkcję pozbawionego własnego głosu obiektu poddanego dydaktycznej tresurze. Jego śmierć służy przede wszystkim wychowaniu hipotetycznego odbiorcy, który otrzymuje prostą lekcję: „Nie słuchać starszych, rzecz bardzo brzydka!” oraz „Kto nie je zupy, ten umrzeć musi”. Opowiadanie Pippi, pozornie identyczne, zmienia rozłożenie akcentów - niechęć do jedzenia konkretnej potrawy przestaje być godnym potępienia buntem przeciwko uświęconemu porządkowi obowiązującemu wszystkie dzieci. Wyeksponowano tu rolę ojca - Hai Shanga i jego uporu. W rezultacie powstaje opowieść o zderzeniu dwóch przeciwstawnych dążeń, z których jedno - dążenie dziecka - ponosi klęskę. Podkreślona przy tym zostaje nieistotność dziecięcego bohatera: tuż po pogrzebie jaskółka złożyła jajka w niezjedzonym gnieździe, zatem „nie poniesiono właściwie żadnej straty”.

\footnotetext{
7 Na to nawiązanie uwagę zwraca Metcalf, nie poddaje go jednak bliższej analizie (Metcalf 1995: 81).

8 W zbiorku Złota różdżka Hoffmann nie stroni od hiperboli i groteski, które to elementy ulegają uwypukleniu w polskim przekładzie Wacława Szymanowskiego. Nie jest to jednak opisywana przez Michaiła Bachtina groteska typu karnawałowego, której immanentną cechą jest według rosyjskiego myśliciela ambiwalencja (Bachtin 1975: 85). U Hoffmanna element groteskowy całkowicie podporządkowany jest zamysłowi dydaktycznemu (Zipes 2001: 152-153).
} 
Dekonstrukcja tradycyjnej powiastki ku przestrodze odbywa się nie tylko na poziomie ideologicznego przekazu, ale obnażona zostaje także charakterystyczna dla niej technika manipulacji odbiorcą, ze szczególnym uwzględnieniem stosunku do prawdy. Tuż po opowiedzeniu historii Hai Shanga i Pettera Pippi poddaje nieznajomą słuchaczkę opresji władzy wynikającej z przewagi fizycznej: „Czemu masz taką dziwną minę? - zwróciła się do niej Pippi. - O co ci chodzi? Nie sądzisz chyba, że siedzę tu i kłamię? Co? No, powiedz lepiej od razu - dodała groźnie, podwijając rękawy" (Lindgren 2011: 46). Przestraszona dziewczynka wybiera dyplomatyczną odpowiedź: „O nie, broń Boże! [...] Nie chcę powiedzieć, że kłamiesz, ale..." (Lindgren 2011: 46), która nie spotyka się jednak z aprobatą Pippi:

Nie chcesz tego powiedzieć? - oburzyła się Pippi. - Wyobraź sobie, że właśnie kłamię. Kłamię tak, że aż mi język czernieje. A może ty rzeczywiście wierzysz, że dziecko może żyć bez jedzenia od maja do października? Każdy przecież wie, że dzieciaki mogą radzić sobie bez jedzenia przez trzy, cztery miesiące, ale od maja do października to przecież arcygłupie. Rozumiesz chyba, że to kłamstwo. Nie pozwalaj, by ludzie wmawiali ci takie bzdury (Lindgren 2011: 46).

Zdanie: „Nie pozwalaj, by ludzie wmawiali ci takie bzdury” można odczytywać jako metatekstowy apel do wirtualnego odbiorcy, któremu uświadamia się, jak absurdalna i nieprawdziwa jednocześnie jest wizja świata ukształtowana w tradycyjnej literaturze dla dzieci. Ryszard Waksmund ujmuje to następująco: „W tym czasie [w XIX w. - przyp. A.M.C.] literatura dla dzieci, jako narzędzie pacyfikacji umysłów i woli, nadal pozostaje w kręgu oświeceniowych złudzeń, separując niedorosłych czytelników od wszystkiego, co trąci kontestacją, herezją i grzechem” (Waksmund 1998: 212). Otwarte nazwanie bzdurą moralizującej historii hołdującej normatywnie szczytnemu wychowawczemu celowi („Nie słuchać starszych, rzecz bardzo brzydka!”) stanowi groteskowe zrównanie jej z nonsensownymi produktami dziecięcej wyobraźni, takimi jak dowolna opowieść Pippi snuta na użytek zadziwionych małych słuchaczy. Moc „pacyfikacji umysłów i woli” zostaje ośmieszona, a zarazem zneutralizowana.

Scena, w której Pippi opowiada poszukującej ojca dziewczynce historię Hai Shanga, po czym płata jej nieładnego psikusa z użyciem groźby pobicia, jest przykładem szczególnie okrutnego zachowania bohaterki Lindgren, niezgodnego z prezentowaną przez nią ciągłą gotowością obrony słabych i bezbronnych (Metcalf 1995: 82). Wyjaśnienia tej niezgodności dostarcza lektura manuskryptu. W zawartej tam pierwotnej wersji cytowanego rozdziału dzieci huśtające się na furtce mija osoba dorosła:

Gdy dzieci w najlepsze zajadały gruszki, drogą wiodącą od miasta nadeszła pewna pani. Widząc dzieci, przystanęła i zapytała: - Czy nie widzieliście mojego męża przechodzącego w pobliżu? - Hm - powiedziała Pippi - a jak wyglądał? Czy miał niebieskie oczy? Tak - odpowiedziała pani (Lindgren 2007: 42). 
Z wyrafinowaną grą kategorią prawdy i zmyślenia skonfrontowano tu zatem nie dziecko, ale „pewną panią". To ona, reprezentantka świata dorosłych, zostaje poddana groteskowej moralizatorskiej lekcji, padając ofiarą opresyjnego szyderstwa Pippi. Na kartach manuskryptu scena opowiadania historii o Hai Shangu jest więc jedną z wielu akcji odwetowych, których bohaterka Lindgren konsekwentnie dokonuje na dorosłych mieszkańcach miasteczka. W następujący sposób recepcję tej zamiany dorosłej kobiety na dziewczynkę podsumowuje Lundqvist: „[...] w latach 40. było z pewnością bardziej uzasadnione pozwolić, by obiektem nieokiełznanych kpin Pippi było dziecko, a nie dorosły. (Niemniej dzisiaj sytuacja uległa odwróceniu: Sposób, w jaki Pippi wyśmiewa się z biednej dziewczynki, nosi cechy niemal znęcania się)" (Lundqvist 1979: 116).

Porównanie manuskryptu powieści Lindgren z wersją opublikowaną ujawnia interesującą prawidłowość. W pierwotnym zamyśle autorskim Pippi znacznie częściej konfrontowała się z przedstawicielami świata dorosłych, przy czym - tak jak w scenie spotkania z „pewną panią” przy furtce Willi Śmiesznotki - konfrontacje te bez wyjątku polegały na próbie sił, zarówno w znaczeniu symbolicznym, jak i dosłownym. Pippi w manuskryptowym wcieleniu ucieka się do obelg, pełnych przemocy gestów, nie waha się też przed naruszeniem cielesnej nietykalności niektórych mieszkańców miasteczka. Nie wykazuje przy tym obecnych w opublikowanej wersji powieści oznak skruchy i żalu, które, niezależnie od tego, czy brać je na poważnie ${ }^{9}$, usprawiedliwiają jej niedostosowane do ogólnie przyjętych zasad zachowanie. „Bardzo przepraszam [...]. Nie wiedziałam tego i już więcej tego nie zrobię" (Lindgren 2011: 36) - odpowiada Pippi „ze skruchą” (Lindgren 2011:36) na uwagę, że do pani w szkole nie wolno zwracać się per „ty”. W manuskrypcie rozmowa z nauczycielką zaczyna się tak samo jak w wersji opublikowanej:

- [...] No, Pippi, czy możesz mi powiedzieć, ile to będzie razem 7 i 5 ? - Pippi spojrzała na panią ze zdumioną i niezadowoloną miną, po czym odpowiedziała: - No, jeżeli sama tego nie wiesz, to nie wyobrażaj sobie, że ja ci powiem! (Lindgren 2007: 36).

Jednak rozwija się inaczej:

Cała klasa wpatrzyła się w Pippi, a pani gwałtownie zaczerpnęła tchu. I szybko zaczęła tłumaczyć Pippi, że w szkole nie wolno odpowiadać w ten sposób i nie wolno mówić na "ty” do pani nauczycielki, że trzeba zachowywać się porządnie i tak dalej. W tym momencie Pippi położyła rudą głowę na pulpicie i powiedziała: - Obudź mnie, jak skończysz kazanie! - Pani ponownie zaczerpnęła tchu, ale pomyślała, że najlepiej będzie postępować z Pippi ostrożnie (Lindgren 2007: 36-37).

9 Według Edström Pippi w tych scenach udaje skruchę (Edström 1992: 87). 
Pippi nie tylko nie okazuje tu skruchy z tytułu nieodpowiedniego zachowania. Kładąc głowę na ławkę w teatralnym geście znudzenia, prezentuje lekceważenie wobec autorytetu. Autorytet też w sposób wyraźny jest przedmiotem gry - zirytowana nauczycielka świadomie ogranicza wachlarz możliwych reakcji, zamiast ewentualnych represji wybierając ostrożne postępowanie. W manuskrypcie relacja Pippi i nauczycielki jednoznacznie nabiera charakteru potyczki. W obecności zdumionego dziecięcego audytorium odbywa się istna szermierka słowna. Pozbawiony uzasadnień i usprawiedliwień bunt Pippi jest tu chłodny i świadomy. Nieprzewidywalna w swoich błazeństwach krnąbrna uczennica do końca nie poddaje się poskramiającym zabiegom nauczycielki - wreszcie zwycięża. W obliczu nieprzystojnej parodii grzecznej piosenki szkolnej, którą Pippi wykonuje, huśtając się na lampie, dobrotliwa i łagodna dotychczas pani traci cierpliwość: „- Koniec szkoły na dzisiaj! - krzyknęła pani przeraźliwie. - Idźcie do domu natychmiast. Natychmiast, słyszycie?!” (Lindgren 2007: 40). Erupcja gniewu zwiastuje ostateczne ogłoszenie kapitulacji, wobec którego triumfująca Pippi okazuje łaskę:

Pippi zwisała teraz z lampy na wyprostowanym ramieniu, a kiedy dzieci zaczęły wychodzić z sali szkolnej, zeskoczyła na podłogę tuż przed panią. - Cóż, do zobaczyska! I wielkie dzięki za dzisiaj - powiedziała, potrząsając serdecznie dłonią nauczycielki. Było naprawdę miło przyjść i zobaczyć, jak się tu miewacie, ale, szczerze mówiąc, raczej nie będę miała czasu na te dziecinne głupstwa w przyszłości. Mam nadzieję, że nie będzie ci przykro, ale fakt jest taki, że już się tu nie pojawię. - Czy mogę na to liczyć? wyszeptała pani, wyczerpana (Lindgren 2007: 40).

Wizytę Pippi w szkole opisaną w manuskrypcie można zatem podsumować Cezariańskim veni, vidi, vici. Nastąpiło chwilowe wrogie przejęcie jednego z przyczółków dorosłej władzy, władczynię zaś - nauczycielkę - strącono z piedestału i upokorzono w obecności oraz w imieniu uczniów - „grzecznych koleżanek i kolegów" (Lindgren 2011: 35) Tommy’ego i Anniki.

W wersji opublikowanej konfrontacja Pippi z panią ma nieco inny przebieg. Łagodnie upominana bohaterka co i rusz wyraża skruchę, w świetle której każdy kolejny pokaz niegrzeczności zdaje się efektem zapomnienia raczej niż złej woli. Utrata przez panią cierpliwości, w manuskrypcie wyrażona implicite w pełnym emocji dialogu, tu objawia się w ramach zobiektywizowanego narratorskiego opisu: „Teraz jednak wyczerpała się cierpliwość nauczycielki. Kazała wszystkim dzieciom wyjść na podwórze szkolne, gdyż chciała pomówić z Pippi na osobności” (Lindgren 2011: 40). Scenariusz tej rozmowy też jest zupełnie inny niż w manuskrypcie:

Gdy zostały same, Pippi wstała i podeszła do katedry. - Wiesz co - zaczęła - to jest, chciałam powiedzieć, wiesz co, pani? Bardzo przyjemnie było przyjść i zobaczyć, jak tu u was jest. Nie wydaje mi się jednak, żebym jeszcze kiedyś miała ochotę przyjść do szkoły. [...] O wiele za dużo było mowy o jabłkach i jeżach, i wężach, i o tym 
wszystkim. Aż mi się w głowie kręci! Chyba się o to nie gniewasz, proszę pani? - Pani odpowiedziała, że owszem, gniewa się, bo Pippi nie chce postarać się zachowywać jak należy, a żadna dziewczynka, która zachowuje się tak jak Pippi, nie może chodzić do szkoły, nawet jeśliby tego bardzo pragnęła (Lindgren 2011: 40).

Również pozycja Pippi względem nauczycielki różni się kontrastowo od tej z manuskryptu. Tam bohaterka wisi na lampie, patrzy więc na panią z góry, po czym zeskakuje, lądując naprzeciwko niej. W wersji opublikowanej początkowo kładzie się na podłodze (kiedy uczniowie wstają, żeby zaśpiewać piosenkę), następnie zaś podchodzi do katedry. Brak jest wzmianki, jakoby miała na nią wejść, nie zachodzi również sytuacja potrząsania dłonią, stąd można wnioskować, że stojąc na katedrze podczas rozmowy, nauczycielka znajduje się wobec Pippi w pozycji wywyższonej. Ex cathedra też brzmią jej słowa - dydaktyczna pogadanka punktująca nienormatywność zachowania (podkreślona zostaje przy tym płeć bohaterki) i zamykająca przed Pippi drzwi szkoły to wyraz triumfu władzy, z której oblicza nie udało się zerwać maski. Postać Pippi uległa więc degradacji - manuskryptowy zwycięski błazen zamienił się w niegrzeczną i kłopotliwą, ale wciąż poskramialną uczennicę:

- Czy ja się źle zachowywałam? - zapytała Pippi z najwyższym zdumieniem. - Ja przecież wcale o tym nie wiedziałam - dodała z żałosną miną. Nikt nie wyglądał tak żałośnie jak Pippi, kiedy jej było przykro. Stała przez chwilę w milczeniu, a potem dodała drżącym głosem: - Rozumiesz chyba, pani, że jak się ma mamusię, która jest aniołem, i tatusia, który jest królem murzyńskim, i jak się samemu przez całe życie pływało po morzach, to wówczas nie bardzo się wie, jak trzeba zachowywać się w szkole wśród tych wszystkich jabłek i jeży. - Wówczas pani powiedziała, że rozumie to, i że nie gniewa się już na Pippi, i że Pippi będzie pewno mogła wrócić do szkoły, gdy trochę wyrośnie (Lindgren 2011: 40).

Nauczycielka sprawuje zatem na terenie szkoły władzę absolutną. Jest jedyną instancją zdolną zaprosić nienormatywną delikwentkę do społeczności uczniowskiej, ale i z niej wykluczyć. Także dobroć i łagodność pani, w manuskrypcie sztuczna i przesłodzona, tutaj nabiera autentyczności, niejako usankcjonowana jej triumfem nad Pippi, która na wieść, że będzie mogła kiedyś wrócić do szkoły, „rozpromieniła się z radości i zawołała: - Uważam, że jesteś strasznie dobra, proszę pani!" (Lindgren 2011: 40). Charakterystyczne jest przy tym, że Pippi ostatecznie rezygnuje z mówienia do nauczycielki per „ty” na rzecz swoistego kompromisu z normatywnym "proszę pani”, podczas gdy w manuskrypcie do końca w użyciu pozostaje familiarny zwrot „ty”.

Rozdział Pippi idzie do szkoły padł ofiarą najrozleglejszych zmian w procesie tłumaczenia na język polski. Na ogół dość wierna oryginałowi, zwłaszcza na tle 
przekładów na inne języki (Surmatz 2007), Irena Szuch-Wyszomirska ${ }^{10}$ zdecydowała się usunąć scenę, w której Pippi wręcza pani złoty zegarek (Dymel-Trzebiatowska 2013: 229), złagodziła też najbardziej ironiczne uwagi pod adresem nauczycielki (Murzynowska i Teodorowicz-Helman 2008: 74-75). Teresa Chłapowska, która redagowała i poprawiała przekład Szuch-Wyszomirskiej na użytek wydania całej trylogii, zachowała te modyfikacje.

Przykładem dorosłego, któremu manuskryptowa Pippi daje nauczkę przy użyciu przemocy fizycznej, jest nieobecny w wersji opublikowanej pan Fredriksson, ojciec chłopca znęcającego się nad słabszymi dziećmi. W Pippi Pończoszance bohaterka konfrontuje się z Bengtem w obronie ofiary prześladowań gangu starszych chłopaków. W Ur-Pippi to ona sama jest przedmiotem zaczepek Ovego (odpowiednika Bengta), reaguje zatem w obronie własnej. Przebieg potyczki jest w obu wersjach podobny - Pippi stoicko znosi wyzwiska, po czym w odpowiedzi na atak cielesny ucieka się do przewagi fizycznej. W powieści Bengt i jego towarzysze zostają przewieszeni przez gałęzie drzewa, słupki furtki i rozrzuceni po okolicznych ogródkach. W manuskrypcie karę ponosi wyłącznie Ove. Na oczach publiczności złożonej z Tommy’ego i Anniki oraz grupy kumpli zostaje sześciokrotnie wyrzucony wysoko w powietrze, przy czym brak obrażeń ciała zawdzięcza temu, że Pippi „była miłą dziewczynką, która nie chciała krzywdzić złych chłopczyków” (Lindgren 2007: 21). Powieściowy wariant tej sekwencji scen kończy się w zasadzie w tym miejscu - wraz z Pippi, Tommym i Anniką czytelnik zostawia Bengta tkwiącego na drzewie, pozbawionego autorytetu oraz głosu: „Lecz Bengt nie miał już nic więcej do powiedzenia ani o włosach, ani o butach Pippi" (Lindgren 2011:22). W manuskrypcie scena ta ma jednak ciąg dalszy. Ove idzie na skargę do ojca, a typ rodzicielstwa, który ten ostatni prezentuje, spotyka się z niezawoalowaną krytyką narratora: „Pan Fredriksson był bardzo niesprawiedliwy. Z a w s z e trzymał stronę Ovego, nawet jeśli Ove był winny. Nie tolerował, żeby ktoś choćby palcem tknął jego ukochanego synusia” (Lindgren 2007: 20). Rozdrażniony skargą potomka „nawet nie zapytał, czy przypadkiem Ove też nie był złośliwy. Po prostu ruszył na ulicę w stronę Pippi, uderzył ją mocno w twarz, szarpnął za rękę i krzyknął: - Już ja cię nauczę znęcać się nad małym Ovem! Wstydź się!” (Lindgren 2007: 22).

Ta demonstracja przemocy fizycznej zastosowanej przez dorosłego wobec dziecka wyróżnia konfrontację z ojcem Ovego na tle pozostałych zdarzeń zarówno w Ur-Pippi, jak i w opublikowanej trylogii. Nie znalazła się na karatach Pippi Pończoszanki, nie zawiera jej Pippi wchodzi na pokład ani Pippi na Południowym Pacyfiku, mimo że autorka wykorzystała niektóre wycięte z manuskryptu motywy i sceny przy okazji pisania drugiego i trzeciego tomu. Znamienny jest tu emocjonalny komentarz

10 Szczegółowej analizy polskich przekładów powieści o Pippi dokonała Hanna Dymel-Trzebiatowska, wykazując szereg zmian w stosunku do oryginału, zarówno o charakterze estetycznym, jak i ideologicznym (Dymel-Trzebiatowska 2013). 
narratorski towarzyszący postaci pana Fredrikssona. Zawiera ironiczne zdrobnienia, podkreślenia, wyrażone explicite diagnozy. W połączeniu z mocną sceną pobicia Pippi stanowi wyrazisty sprzeciw wobec opresyjnej władzy świata dorosłych nad światem dzieci.

Biorąc odwet na panu Fredrikssonie, Pippi staje nie tylko w obronie własnej, ale i wszystkich dzieci, które kiedykolwiek bito, zarówno postaci literackich, jak i dzieci rzeczywistych, w tym także hipotetycznego czytelnika. Jej całkowity triumf nad ojcem Ovego można wręcz uznać za terapeutyczny, tak wielką satysfakcję daje odbiorcy:

Pippi spojrzała na niego spokojnie. Pan Fredriksson miał bardzo duży nos, więc po chwili powiedziała: - Jaki świetny uchwyt masz na środku twarzy! - Po czym chwyciła mocno nos pana Fredrikssona. Piorun z jasnego nieba nie wywołałby u niego większego zdumienia. Wpadł też we wściekłość, bo nie był przyzwyczajony, żeby dzieci broniły się, gdy je bił. Wierzgnął dziko, żeby się uwolnić, ale Pippi nie zwalniała chwytu. - Ach, jaka piękna dziś pogoda, wspaniałe słońce - stwierdziła uprzejmie. - Powinniśmy iść na spacer, ty i ja. - Po czym poprowadziła pana Fredrikssona za nos tam i z powrotem po ulicy. Przez cały czas przemawiała do niego uspokajająco. - Duzi, silni wujaszkowie nie powinni bić małych, bezbronnych dziewczynek. Jeśli już koniecznie $\mathrm{m}$ u s is z się bić, możesz przyłożyć Ovemu od czasu do czasu. Przydałoby mu się. - Następnie puściła pana Fredrikssona, a on, blady z wściekłości, poszedł do domu (Lindgren 2007: 22).

„Pewna pani”, nauczycielka i ojciec Ovego z manuskryptu oraz obłudna filantropka, policjanci i dyrektor cyrku z opublikowanej wersji trylogii stanowią kolejne cele wojny podjazdowej, którą nieustannie prowadzi Pippi. Świat dorosłych, przybierający najrozmaitsze twarze - indywidualne i zbiorowe, osobiste i instytucjonalne, opresyjne i mniej opresyjne - jest w sposób oczywisty wrogi. Dorośli i dzieci stanowią zatem nie tylko odrębne, ale wręcz zantagonizowane grupy, a dokonująca się między nimi próba sił zawiera istotny przekaz ideologiczny. Radykalizm i bezkompromisowość tego przekazu okazały się przełomowe. Pojawienie się Pippi Pończoszanki miało nie tylko skutki doraźne w postaci ogólnoszwedzkiej debaty na temat literatury dziecięcej, ale także zapoczątkowało rewolucyjną zmianę w kwestii podmiotowości dziecięcego bohatera. Nie będzie przesadą stwierdzenie, że to za sprawą Pippi szwedzka literatura dla niedorosłych jest obecnie jedną z najbardziej postępowych na świecie. Za pośrednictwem swojej superbohaterki Lindgren udało się dokonać zwrotu ideologicznego, dzięki któremu podstawą filozoficzną twórczości dla młodych w Szwecji przestała być pedagogia - stały się nią prawa dziecka. 
Bibliografia

Abate, M. (2008). Tomboys. A Literary and Cultural History. Philadelphia: Temple University Press.

Andersen, J. (2014). Denna dagen, ett liv. En biografi över Astrid Lindgren. Tłum. U. Andersson. Sztokholm: Norstedts.

Bachtin, M. (1975). Twórczość Franciszka Rabelais'go a kultura ludowa średniowiecza i renesansu. Tłum. A. Goreń i A. Goreń. Kraków: Wydawnictwo Literackie.

Bergstrand, U. (1999). Maten i barnboken. W: U. Bergstrand i M. Nikolajeva (red.). Läckergommarnas kungarike. Om matens roll i barnlitteraturen. Stockholm: CBK, s. 43-84.

Cieślikowski, J. (1975). Literatura i podkultura dziecięca. Wrocław: Ossolineum.

Dymel-Trzebiatowska, H. (2013). Translatoryka literatury dziecięcej. Analiza przekładu utworów Astrid Lindgren na język polski. Gdańsk: Wydawnictwo UG.

Edström, V. (1992). Astrid Lindgren. Vildtoring och lägereld. Stockholm: Rabén \& Sjögren.

Hoffmann, H. (1933). Złota różdżka. Czytajcie dzieci, uczcie się, jak to niegrzecznym bywa źle. Tłum. W. Szymanowski. Warszawa: Wydawnictwo Tanich Książek dla Dzieci i Młodzieży.

Kåreland, L. (1999). Modernismen i barnkammaren. Barnlitteraturens 40-tal. Stockholm: Rabén \& Sjögren.

Key, E. (1900). Barnets Århundrade. Stockholm: Alb. Bonniers Boktryckeri.

Lindgren, A. (1964). Det började i köket hos Kristin... W: B. Strömstedt (red.). Min väg till barnboken. 21 barnbokförfattare berättar. Stockholm: Bonnier, s. 127-134.

Lindgren, A. (2007). Ur-Pippi. Originalmanus. Stockholm: Rabén \& Sjögren.

Lindgren, A. (2011). Przygody Pippi. Tłum. I. Szuch-Wyszomirska i T. Chłapowska. Warszawa: Nasza Księgarnia.

Lundqvist, U. (1979). Århundradets barn. Fenomenet Pippi Långstrump och dess förutsättningar. Stockholm: Rabén \& Sjögren.

Lundqvist, U. (2007). Komentarer. W: A. Lindgren. Ur-Pippi. Originalmanus. Stockholm: Rabén \& Sjögren.

Metcalf, E. (1995). Astrid Lindgren. New York: Twayne.

Murzynowska, D. i E. Teodorowicz-Helman. (2008). Pippi Pończoszanka w polskim dyskursie kulturowym. W: H. Dymel-Trzebiatowska i E. Mrozek-Sadowska (red.). Astrid Lindgren 100 lat: interpretacje. Gdańsk: Pressfabryka, s. 67-86.

Rowbotham, J. (1989). Good Girls Make Good Wives. Guidance for Girls in Victorian Fiction. Oksford: Blackwell.

Sandemose, A. (2019). Uciekinier przecina swój ślad. Opowieść o dzieciństwie mordercy. Tłum. I. Zimnicka. Warszawa: Czarne.

Surmatz, A. (2007). International Politics in Astrid Lindgren's Works. Barnboken 1-2 (30): 24-37.

Sznajderman, M. (2000). Błazen. Maski i metafory. Gdańsk: Słowo/obraz terytoria.

Waksmund, R. (1998). Dziecko nie święte. W: J. Papuzińska i G. Leszczyński (red.). Dziecko i sacrum. Studia i szkice literackie. Warszawa: Polska Sekcja IBBY, s. 209-226.

Zipes, J. (2001). Sticks and stones. The troublesome success of children's literature from Slovenly Peter to Harry Potter. New York: Routledge. 